\title{
REFLEKSI PENELITIAN: DARI MASYARAKAT EKSOTIS KE KOMUNITAS KAMPUS DAN CAFE
}

\author{
Yevita Nurti ${ }^{1}$
}

\begin{abstract}
This paper is a reflection of the research in order to exercise anthropological research on the subject Theory, Methods and Practice research at the University of Indonesia. Research with the general theme of campus life and field settings the University of Indonesia, became an interesting experience, especially regarding the crucial issues in contemporary anthropological research, ranging from determining the themes and research plan, to the data collection. How anthropology as a discipline capable of responding to the shifts that occur and require changes to the workings of anthropology, not only change research techniques but also requires the redefinition of the various concepts.
\end{abstract}

Key words: Research, Anthropological, Campus, Cafe, University of Indonesia

\section{A. Pendahuluan}

$\mathrm{M}$ asih segar diingatan ketika Tim Dosen pengampu mata kuliah Penelitian Antropologi: Teori, Metode dan Praktek, mengatakan bahwa masing-masing peserta akan melakukan tugas praktik penelitian secara individual atau tidak berkelompok. Praktik penelitian ini dilakukan selama satu semester, yang praktis hanya berlangsung selama 4 bulan, dipotong masa untuk menyiapkan proposal, masa untuk memikirkan dan membuat koding serta memoing, masa untuk membuat laporan, menelusuri bahan pustaka yang relevan, dipotong masa liburan Idul Fitri, dan ampuun... semua merupakan tugas individu. Kita kan juga harus berkutat dengan tugas-tugas mata kuliah lainnya, celetuk salah seorang teman... semiloka teori, semiloka metodologi, mata kuliah teori.... Saya mulai bingung dan khawatir, bisakah penelitian ini dilakukan? Mampukah kami masing-masing peserta melakukan penelitian secara mandiri dalam waktu singkat? Seperti apa hasilnya nanti? Tercapai apa tidak ya?

Tentu saja saya bingung bukan kepalang karena setahu saya, penelitian antropologi dengan metode kualitatif sangat menekankan kedalaman dalam memahami realitas, di mana seorang peneliti 'menceburkan' dirinya dalam realitas, memahami dengan baik setiap 'tetes' realitas, kemudian 'meramu dan menjalin' realitas itu ke dalam berbagai bentuk penulisan etnografi. Ibarat menjelaskan hutan rimba, maka peneliti kualitatif akan hidup di tengah hutan rimba tersebut, menyibak sisi terdalam dari rahasia dan jejak realitas hutan rimba di alam semesta serta memahaminya dengan baik. Setidaknya, inilah yang menjadi ciri khas dari seorang antropolog yaitu memasuki satu setting lapangan, mengikuti jejak-jejak sebuah realitas, kemudian menautkannya secara utuh dalam sebuah bingkai etnografi.

Namun saya teringat kembali apa yang dikatakan salah seorang dari Tim Dosen, bahwa dalam mata kuliah ini masing-masing peserta akan melakukan 'latihan' penelitian antropologi. Artinya, saya sadar betul bahwa tujuan mata kuliah ini adalah agar kami (para peserta mata kuliah) mengerti dan menjalani bagaimana seharusnya penelitian antropologi itu dilakukan, step by step nya, membuat koding dan memoing, sehingga ke depan kami tidak membuat sebuah etnografi hanya berdasarkan apa yang kami pikirkan saja. Jadi bukan hasil akhir yang paling penting di sini, tetapi bagaimana proses untuk

\footnotetext{
${ }^{1}$ Penulis adalah dosen tetap jurusan Antropologi FISIP Universitas Andalas, Padang
} 
mendapatkan hasil akhir itu dilalui dan dialami. Sebuah proses --yang bisa jadi-belum kami lakukan sesuai dengan prosedur yang sesungguhnya.

\section{B. Setting: Kampus Universitas Indonesia}

$\mathrm{P}$ ertanyaan lain yang menggelayut di benak saya adalah mengapa Tim Dosen pengampu mata kuliah 1; Atau seperti yang disadari Geertz sekitar tahun 1950-an, bahwa "mereka di sana memiliki kebudayaan, dan tugasmu adalah kembali ke sini dan menceritakan seperti apa kebudayaan mereka", Atau ini merupakan tantangan metode antropologi dalam masyarakat yang berubah, sejalan dengan perkembangan manusia dan masyarakat, perkembangan teknologi informasi, komunikasi, dan sebagainya telah membawa perubahan besar dalam hidup manusia ${ }^{3}$. Kini, masyarakat tidak lagi homogen dan terperangkap dalam kategori yang khas dan berada pada satu ruang geografis tertentu (boundary) ${ }^{4}$. Masyarakat kian bergerak menuju kategori tanpa tapal batas (borderless society).

1 Talal Asad mencurigai formasi pengetahuan antropologi sangat bias Eropa barat dan kolonialisme. Ini menyebabkan antropologi menjadi alat bagi negara penjajah untuk menguasai daerah jajahan.

2 Clifford Geerzt: After the fact: Dua negeri, Empat dasawarsa, Satu Antropolog (alih bahasa Landung Simatupang). Yogyakarta: LkiS. 1998 : 67.

${ }^{3}$ Irwan Abdullah (2006) Konstruksi dan

Reproduksi Kebudayaan. Yogyakarta: Pustaka Pelajar.

${ }^{4}$ Istilah boundary menggambarkan adanya batasan geografis yang membingkai sebuah masyarakat. Kebudayaan masyarakat itu masih bisa dikenali dengan jelas berdasarkan letak geografis itu. Seiring dengan globalisasi dan revolusi di bidang komunikasi dan informasi, batasan itu mulai mengabur. Masyarakat mulai berkembang ke kategori borderless society, sehingga isu yang ada pada satu masyarakat bisa jadi dipengaruhi oleh apa yang terjadi di masyarakat lain. Lihat juga Abdullah (2006) Konstruksi dan Reproduksi Kebudayaan dan Lihat juga Tsing, Anna Lowenhaupt (2005) Etnography of Global Connection. New Jersey: Princeton University Press sepakat memilih kampus UI sebagai setting penelitian. Apakah ini berkaitan dengan kritik tajam terhadap kajian-kajian antropologi sebelumnya?, dimana para antropolog seolah-olah masih diselubungi oleh imajinasi para penjelajah Eropa yang terobsesi untuk menemukan masyarakat primitif untuk dianalisa dan dilabel dalam dalam satu kategori.

Appadurai (1994) mengajukan tesis tentang pergeseran ruang dalam masyarakat ini ${ }^{5}$. la melihat adanya perbedaan lanskap maupun lingkungan sehingga menegaskan perubahan landasan dari cara kerja antropologi. Di saat kota mulai muncul dan antropologi mulai meneliti kota tahun 1970an (Foster \& Kemper, 1974) ${ }^{6}$, maka cara kerja antropologi mulai dipertanyakan: apakah penelitian antropologi yang sebelumnya dipakai untuk meneliti masyarakat "kecil" dan homogen dapat digunakan dengan kekuatan yang sama pada saat meneliti masyarakat plural. Kompleksitas persoalan yang kian melanda masyarakat ini kini membutuhkan landasan kerja baru. Persoalan yang ada pada satu masyarakat atau komunitas, tidak lahir begitu saja, melainkan dipengaruhi oleh dinamika yang terjadi baik pada tingkat lokal, nasional, maupun internasional. Ruang dan interaksi sosial kian memadat. Penjelasan terhadap gejala atau apa yang terjadi pada satu masyarakat, bisa ditelusuri dengan melihat interaksi serta dinamika yang terjadi pada berbagai level, baik lokal, nasional, maupun internasional. Tema-tema atau tulisan yang menyangkut antropologi kritis di era globalisasi tersebut di atas telah tertuang dalam tulisan-tulisan Appadurai $(1994)^{7}$, Talal Asad $(1973)^{8}$, James Clifford $(1986)^{9}$, serta Marcus $(1998)^{10}$.

${ }^{5}$ Senada dengan Appadurai, sosiolog Anthony Giddens menyebut globalisasi tidak sekadar pergeseran ruang. Baginya, globalisasi mengimplikasikan adanya pelipatan ruang dan waktu

6 Foster, G.M. dan R.V. Kemper (1974). "Introduction: Perspective on Anthropological Fieldwork in Cities", dalam G.M. Foster \& Robert V Kemper (ed), Anthropologist in Cities. Boston: Little, Brown and Company. Hal. 1-18.

${ }^{7}$ Lihat Appadurai A (1994) Global Ethnoscapes: Notes and Queries for Transnational 
Bisa jadi, setting dalam kehidupan kampus yang ditetapkan oleh Tim Dosen sebagai jendela untuk menyelami realitas baru yang merupakan kondisi objektif yang bakal dihadapi antropolog dalam setiap penelitian. Realitas baru dimana cara kerja antropologi yang mulai menuntut adanya perubahan, tidak hanya perubahan teknikteknik penelitian yang sebelumnya dipakai untuk meneliti masyarakat "kecil" dan homogen, tetapi juga diperlukan pendefinisian ulang berbagai konsep. Sebut saja misalnya konsep keluarga, pada saat solidaritas anggota keluarga bergeser akibat mobilitas secara umum, misalnya, maka definisi lama tidak lagi mampu menjadi wakil dari penjelasan apa itu keluarga. Seperti dikatakan Abdullah (2006), tanpa perubahan asumsi-asumsi dasar dan definisi-definisi konsep, atau paling tidak tanpa menyadari kondisi objektif tersebut, para antropolog justru akan tersesat ke dalam rimba modern: seorang antropolog tidak ubahnya seperti seseorang dari suku terasing yang datang ke kota besar. Dengan peta pengetahuan lama, dia tidak akan dapat bertahan dalam lingkungan baru. Kekhawatiran-kekhawatiran seperti ini dialami oleh Kurotani (2004) ${ }^{11}$ dan Muir $(2004)^{12}$ dalam penelitiannya. Kurotani

Anthropology dalam RG Fox (ed) Recapturing Anthropology: Working in the Present. Santa Fe, NM: School of American Research Press.

8 Asad, Talal (1973) Anthropology and the Colonial Encounter, Ithaca: Humanities

${ }^{9}$ Clifford, J.R.Marcus (1986). Writing Culture: The Poetics and Politics of Etnography. Berkley: University of California Press

10 Marcus, George E. (1998). Ethnography: Through Thick \& Thin. New Jersey: Princeton University Press

11 Kurotani, Sawa. 2004. "Multi-sited Transnational Ethnography and the Shifting Construction of Fieldwork" dalam dalam Anthropologist in the Field: Cases in Participant Observation, Lynne Hume \& Jane Mulcock (eds). New York: Columbia University Press.

12 Muir, Stewart. 2004. "Not Quite at Home : Field envy and New Age Ethnographic Disease", dalam Anthropologist in the Field: Cases in Participant Observation, Lynne Hume \& Jane Mulcock (eds). New York: Columbia University Press. mencoba melihat ruang domestik sebagai pertemuan lokal-global, dan menjelaskan tentang implikasi mobilitas transnasional pada istri-istri businessmen Jepang. Dia bukan meneliti masyarakat eksotik, melainkan masyarakat yang sangat "cair", dan para subjek penelitiannya tinggal bukan pada satu wilayah tapi di kota yang beragam. Kecemasan yang menderanya membuat dia merasa harus memperbaiki cara-cara penelitian klasik dan menyesuaikan dengan kondisi lapangan saat ini. Begitu juga penelitian Muir (2004), yang meneliti pada masyarakat Aborigin yang terkena globalisasi, sehingga kultur lokal menjadi "buyar". Akibatnya lapangan penelitian yang tadinya sebuah desa, atau sebuah kampung, sekarang menjadi kafe, gedung perkantoran, atau ruang "chatting" internet. Di sini terjadi semacam ketakutan, kekhawatiran, putus asa, atau kegagalan dalam etnografinya, apakah metode penelitian antropologi klasik masih bisa dipakai dalam kondisi perubahan seperti ini? Muir pun menyarankan supaya cara berfikir kita selama ini tentang lapangan kajian harus direvisi.

\section{Rancangan Penelitian}

\section{Penentuan Tema Penelitian}

$\mathrm{B}$ ermula dari kebiasaan kami setelah selesai kuliah selalu mencari tempat makan karena lapar. Pada hari itu salah seorang dari teman saya (Jasmin) nyeletuk : "kita cari tempat makan lain yuk! Bosan makan di kantin ini terus". Kantin yang dimaksud Jasmin adalah kantin PAU FISIP UI, dan kebetulan hari itu kantin tersebut tutup. Saya menyambut ajakan tersebut dan menawarkan cafe bloc yang ada di gedung Koentjaraningrat. Saya katakan kepada kedua teman saya itu, maksud dan tujuan saya mengajak makan di cafe bloc adalah sekalian untuk observasi untuk menemukenali topik dan permasalahan penelitian dalam rangka mata kuliah metodologi, teori dan praktik. Rupanya kedua teman saya setuju, lalu kami berjalan menuju cafe bloc tersebut.

Sesaat sebelum memasuki cafe bloc, saya membaca judul café yang terpajang di dinding depan café: Books Lounge Café (bloc). Tulisan bloc ditulis 
dengan huruf kecil tetapi ukurannya besar. Kata bloc ditulis dengan cat warna kuning tua. Di atas kata bloc, agak ke pinggir kanan, tertulis books lounge café dengan huruf kecil juga tetapi ukurannya lebih kecil dari kata bloc dan dibawah kata bloc tertulis let's your intellect dance yang ditulis dengan huruf kecil kecuali awal kata ditulis dengan huruf besar. Kata 'let's your intellect dance' dan 'books lounge café' ditulis dengan warna cat ungu. Saya baru sadar bahwa nama cafe bloc tersebut adalah singkatan dari Books Lounge Café. Judul Books Lounge Cafe terletak di dinding tengah antara dua pintu masuk. Satu pintu masuk menuju café dan satu lagi pintu masuk menuju toko buku.

Dari luar saya dapat melihat aktivitas di dalam cafe, walaupun sedikit gelap, karena dinding-dinding terbuat dari kaca. Pintu masuk juga terbuat dari kaca. Kaca-kaca tersebut sama sekali tidak ditutupi oleh gorden atau apapun, sehingga aktivitas orang-orang di dalam cafe bisa tampak jelas dari luar.

Pada saat kami masuk ke cafe bloc, saya merasakan suasana yang berbeda dengan beberapa kantin tempat makan yang biasa kami datangi. Tentu saja terasa adem dan interior yang berbeda yang mengingatkan saya pada suasana dan interior cafe yang ada di mal atau cafe yang ada di luar kampus. Setelah kami memilih tempat duduk di sofa, segera pelayan cafe menghampiri dan memberikan daftar menu yang di tik dan dilaminating rapi. Interior, kesejukan dan kenyamanan café, menu yang relatif lengkap dan beragam dari berbagai tempat, mulai dari steak ala Barat, tomyam khas China, pasta Italia, bahkan nasi goreng rumah dan nasi goreng khas ala bloc, pelayanan, daftar menu yang dilaminating, dan sebagainya membuat tempat makan yang satu ini sangat kontras dengan tempat makan (kantin) yang ada di sekitarnya.

Perbedaan cafe dengan tempat makan (kantin) yang biasa saya datangi di kampus adalah harga makanan di cafe lebih mahal dibandingkan dengan harga makanan di kantin. Untuk sepiring nasi dengan sepotong lauk (bisa ayam goreng atau ikan goreng) dan sebotol air mineral aqua di kantin PAU FISIP saya hanya merogoh kantong hanya sekitar Rp. 10.000 saja. Jika di kantin takor atau kantin lainnya, sepiring nasi dengan sepotong lauk hanya sekitar Rp. 8.000 saja. Namun, harga makanan di cafe bloc berkisar antara Rp. 13.000 sampai Rp. 30.000 dan harga minuman mulai dari Rp. 6.000 sampai Rp. 18.000 . Bedanya lagi, harga makanan di cafe bloc ditambah /dikenakan pajak atau tax $10 \%$ dari jumlah makanan yang sebenarnya. Berarti jika saya makan di cafe, saya mengeluarkan uang untuk 2 kali makan di kantin PAU. Kesan mahal ini juga tersimpan dalam otak saya. Seketika saya juga berfikir, familiarkah harga-harga menu di cafe ini dengan kantong mahasiswa yang notabene cekak, dan dijatah tiap bulannya. Atau setidaknya, ketersediaan dana atau uang menjadi syarat untuk bisa makan di cafe bloc ini. Mungkinkah cafe hanya didatangi oleh kalangan tertentu saja? Atau Cafe mungkin menjadi ajang bagi kaum berduit kampus dan orang-orang kelas tertentu saja? Semua pemikiran ini tentu saya simpan dalam hati saja dulu.

Sambil menunggu pesanan makanan, saya kembali melihat jenis-jenis makanan dan minuman yang tertulis di kertas yang dilaminating tersebut. Menu makanan cukup beragam mulai dari makanan (food), sandwich, salad, soup, pasta, snack, bloc breakfast menu, coklat, dan minuman. Yang menarik bagi saya adalah nama-nama makanan tersebut beragam pula, ada yang menggunakan istilah makanan Itali (pasta / spaghetti), nasi goreng Indonesia, Tom Yum Soup (makanan khas Cina), ayam goreng DabuDabu, steak, dan sebagainya. Saat itu otak saya berputar untuk mengenali apakah cafe ini cerminan globalisasi atau sekedar gaya saja menulis nama-nama makanan dalam bahasa asing. Namun ada juga makanan khas asli Indonesia, yaitu nasi goreng, dan saya mulai berfikir apakah ini percampuran lokal - global. Apakah dialektika lokal global saja yang menjadi fokus penelitian saya. Berbagai pemikiran ini saya simpan dulu untuk sementara.

Sementara kami menikmati makanan, datang beberapa anak muda, yang terdiri dari 3 orang perempuan dan 1 orang laki-laki. Mereka duduk persis di sofa yang berada di depan kami. Saya terus mengamati mereka sambil menikmati makanan saya. Seorang anak muda yang perempuan duduk di karpet didampingi oleh seorang anak muda laki-laki. Yang 
perempuan lalu mengeluarkan laptop dari tasnya dan mereka berdua lalu berbincangbincang seperti mendiskusikan apa yang dilihat pada layar laptopnya. Sementara 2 anak muda perempuan lainnya duduk di sofa dengan santai separuh tiduran. Sesekali mereka melihat ke layar laptop jika mereka diminta ikut untuk menanggapi apa yang ada di layar laptopnya. Saya berusaha mendengar apa yang mereka perbincangkan. Tampaknya mereka mendiskusikan tugas salah satu mata kuliah yang telah dibuat oleh salah satu temannya itu. Tidak lama kemudian datang temanteman mereka 4 orang, dua laki-laki dan dua perempuan. Satu teman yang laki-laki yang baru datang langsung mengambil posisi tidur di sofa, yang lainnya duduk di sofa. Jadi posisinya satu orang tidur di sofa, 5 orang lainnya duduk di sofa itu juga, dan 2 orang duduk di karpet dengan laptopnya. Kemudian salah seorang yang duduk di sofa pindah duduk ke karpet dan mengeluarkan laptop dari tasnya.

Saya terus mengamati sekelompok anak-anak muda ini. Tampaknya hanya yang duduk di depan laptop yang agak serius berdiskusi tentang tugas yang telah dibuatnya. Mereka yang duduk di sofa dan seorang yang tidur di sofa malah sibuk bercanda saja. Sesekali tertawa mereka agak keras. Setelah agak lama, mereka memanggil pelayan dan memesan makanan. Namun tidak semua mereka yang memesan makanan.

Mengamati tingkah laku mereka saya jadi bingung. Mengapa mereka tidak terlebih dahulu memesan makanan? Bukankah orang datang ke cafe karena ingin makan? Apakah mereka datang ke cafe hanya untuk bersantai atau berdiskusi saja. Apakah fungsi cafe sudah berubah menjadi ajang ruang keluarga, untuk bersantai, bersenda gurau, dan sebagainya. Nah pertanyaan-pertanyaan bodoh ini saya pikir bisa dijadikan landasan untuk memilih topik penelitian. Kalau begitu masalah perubahan fungsi cafe saja yang menjadi topik penelitian saya.

Akhirnya, dari sekian banyak pertanyaan bodoh yang muncul selama pengamatan dan sedikit wawancara di cafe, saya cukup tertarik dengan harga makanan yang relatif lebih mahal di cafe ketimbang kantin-kantin yang ada di FISIP UI. Pertama, harga mahal tersebut tentu mensyaratkan kepemilikan uang, dan ini akan berkaitan dengan klas sosial dan status, dan bisa jadi makanan yang dimakan tentu tidak sekedar untuk pemenuhan kebutuhan atau memenuhi rasa lapar saja. Kedua, siapa saja mahasiswa yang datang ke cafe tersebut dan apa alasan utama mereka makan di cafe? Mengapa bukan di kantin saja, toh harganya lebih murah. Makanan adalah simbol, pikir saya. Teringat apa yang dikatakan Creswell, pada dasarnya sebuah topik atau masalah yang diperoleh belumlah merupakan masalah penelitian. Sebuah masalah, dapat didefinisikan sebagai issu yang ada dalam literatur, teori atau praktek, yang memerlukan sebuah kajian/penelitian (Creswell, 1994: 48). Dengan demikian, diperlukan sebuah pernyataan atau argumentasi mengapa atau apa dasar pemikiran topik atau masalah yang diminati tersebut penting untuk dipelajari. Setidaknya pada saat itu, konsep-konsep yang ada di kepala sangat mempengaruhi ketika kita melihat fenomena empirik di lapangan. Kemudian, dengan merumuskan permasalahan penelitian berdasarkan pada makanan sebagai simbol, saya mempresentasikan statement of intent di kelas. Tim Dosen sangat setuju dan saya dipersilahkan melanjutkan penelitian tersebut.

\section{Rencana Penelitian}

$\mathrm{D}$ dalam literatur antropologi, ada beberapa tahapan proses penelitian lapangan, yang sering berbeda satu sama lainnya. Sebut saja misalnya, Gary Ferraro $(1995: 86)^{13}$ mengusulkan tahapan proses: memilih permasalahan penelitian, merumuskan desain penelitian, mengumpulkan data, menganalisa data, dan menginterpretasi data. Sedang John W. Creswell $(2002: 139)^{14}$ menuliskan prosedur penelitian kualitatif adalah mengajukan asumsi desain kualitatif, menetapkan jenis khusus desain penelitian, menggambarkan peran peneliti, membahas pengumpulan

${ }^{13}$ Ferraro, Gary, 1995. Cultural Anthropology: An Applied Perspective ( ${ }^{\text {nd }}$ edition). Minneapolis/ St.Paul: West Publishing Company

${ }^{14}$ Creswell, John W., 2002. Desain Penelitian: Pendekatan Kualitatif \& Kuantitatif

(Alih bahasa: Angkatan III \& IV KIK-UI). Jakarta: KIK Press. 
data, menentukan prosedur pencatatan data, mengidentifikasi prosedur analisa data, menyebutkan langkah-langkah pembuktian, menggambar hasil naratif penelitian. Meskipun tidak pernah ada dua pengalaman penelitian lapangan yang sama, namun rangkaian tahapan semua studi memiliki acuan yang sama dalam prosesnya, yaitu : Memilih permasalahan penelitian - Merumuskan desain penelitian Mengumpulkan data - Menganalisa data Menginterpretasi data dan mempresentasikan hasil penelitian.

Sebelum melakukan sebuah penelitian, terlebih dahulu haruslah membuat rancangan penelitiannya. Rancangan ini biasanya merupakan sebuah blueprint atau pemetaan yang akan membantu etnografer mengkonseptualisasikan bagaimana masing-masing langkah akan dilakukan sebelum membangun pengetahuan dan pemahaman di lapangan (Fatterman, 1989: $18)^{15}$. Rancangan penelitian etnografi ini memuat beberapa poin seperti : masalah penelitian, merumuskan kerangka konsep dan teori, dan merumuskan metode dan teknik penelitian yang akan digunakan.

Dalam konteks penelitian ini, desain penelitian saya tentukan setelah terlebih dulu melakukan observasi (pengamatan) di cafe. Namun demikian meskipun tema permasalahan telah dirumuskan dalam proposal, namun tema tersebut dapat saja berubah untuk menyesuaikan dengan kondisi realitas di lapangan atau perubahan juga dapat terjadi karena pengaruh dari sponsor yang mendanai penelitian yang dilakukan (lihat Marzali, 2003; dan juga Spradley, 1976, dalam Trouble in the Tank). Dengan tema makanan sebagai simbol $^{16}$, saya memutuskan melakukan

${ }^{15}$ Fetterman, David M. 1989. Ethnography Step by Step. Applied Social Research Methods Series Volume 17. Sage Publications: The International Professional Publishers Newbury Park, London, New delhi.

${ }^{16}$ Setiap kali saya mengatakan akan meneliti tentang makanan dan café, semua teman saya mentertawai saya. Malah ada yang lebih ekstrim mengatakan apa sih yang perlu diteliti dalam makanan. Namun saya tetap 'kekeh' mau melakukan penelitian ini karena menurut saya makanan dan café hanya ditempatkan sebagai penelitian ini dalam satu lokalitas yang disebut cafe. Oleh karena cafe terletak di kampus maka, saya berasumsi bahwa pengunjung cafe terbanyak tentulah para mahasiswa dari berbagai jurusan dan fakultas di kampus Universitas Indonesia. Seperti yang disarankan oleh Marcus (1991), salah satu strategi untuk menata ulang etnografi adalah dengan memusatkan pada lokalitas sebagai kerangka acuan etnografi. Hal ini dimaksudkan agar supaya proses-proses transnasional masuk meresap ke setiap penjuru masyarakat atau komuniti, untuk itu diperlukan fokus pada lokalitas bukan lagi pada komuniti.

\section{Pengumpulan Data}

\section{a. Perasaan Canggung}

Derasaan pertama kali akan memasuki cafe untuk melakukan pengamatan dan wawancara adalah bingung, dan mau mulai dari mana penelitian ini. Pengalaman penelitian etnografi selama ini yang pernah saya lakukan adalah datang ke suatu masyarakat, di desa ini atau desa itu, dengan wilayah administratif yang jelas, dan mencari seseorang yang menjadi tokoh masyarakat atau tokoh pemuda di desa itu. Ini seperti cara-cara atau tahapan memasuki setting penelitian yang pernah ditulis oleh Parsudi Suparlan (1997), yaitu :

- Menghubungi pejabat pemerintah setempat untuk memperoleh informasi dan dukungan penelitian yang ingin dilakukan di masyarakat. Si pejabat ini dinamakan sebagai gate-keeper.

- Peneliti harus meminta bantuan pejabat tersebut untuk menunjukkan siapa warga masyarakat yang dapat dijadikan sebagai informan kunci, orang yang dapat menjadi juru/guru bahasanya atau pemberi informasi yang pertama dan mendasar mengenai masyarakat dan kebudayaan yang akan ditelitinya, dan sekaligus orang yang dapat memperkenal-kannya kepada warga masyarakat tersebut.

- Peneliti harus memperkenalkan diri; siapa dirinya dan apa tujuannya berkaitan dengan kegiatan-kegiatan

jendela dalam kehidupan sosial. Ketika jendela itu dibuka maka akan terlihat berbagai aktivitas manusia disana. 
yang dilakukannya dalam masyarakat tersebut, agar masyarakat tahu apa yang akan dilakukan oleh peneliti sehingga mereka tidak mencurigai kegiatan peneliti. Karena peneliti harus diperlakukan oleh masyarakat setempat sebagai orang netral, tidak memihak, dimana di satu pihak peneliti akan diperlakukan sebagai warga masyarakat setempat, tetapi di lain pihak, dia bukan warga masyarakat itu.

\section{Dalam konteks penelitian ini,} bagaimana mungkin langkah yang dianjurkan Parsudi itu dilakukan. Siapa yang musti saya hubungi sebagai gatekeeper, apakah saya perlu mendapatkan izin dari pemilik cafe atau managernya? Jasmin memberikan saran kalau saya langsung saja mewawancarai orang/pengunjung cafe tanpa harus memberi tahu manager atau pemilik cafe. Tapi kemudian saya berfikir, apakah dengan kehadiran saya di cafe dan melakukan wawancara tidak akan mengganggu pengunjung cafe yang sedang makan dan asyik bersantai ria? Jika mereka merasa terganggu, dan melaporkan kepada pihak cafe, maka aktivitas penelitian saya bisa terganggu bahkan mungkin saja izin penelitian dicabut. Akhirnya saya putuskan untuk bertanya sepintas lalu kepada pegawai dan pelayan cafe, terutama mengenai sejarah cafe. Lalu sang pelayan cafe mengatakan bahwa ia tidak berani memberikan informasi kecuali atas izin manager. Kesempatan ini tidak saya siasiakan untuk berkenalan dengan manager dan mewawancarainya, walaupun akhirnya manager tetap meminta surat keterangan resmi dari program pasca.

Satu hal lagi yang membuat saya merasa canggung ketika memulai penelitian ini adalah bahasa. Dalam pengalaman penelitian etnografi, biasanya faktor bahasa sangat menjadi perhatian. Setidaknya butuh waktu untuk penyesuaian dengan bahasa masyarakat yang menjadi sasaran penelitian. Mempelajari bahasa penduduk asli menjadi dasar dari penelitian lapangan dan sekaligus merupakan langkah awal dan paling penting untuk mencapai tujuan utama etnografi ${ }^{17}$. Begitu juga pengalaman Geertz

17 Spradley (1997: 23). Metode Etnografi. Yogyakarta: Tiara Wacana Yogya.
$(1998)^{18}$, Maunati $(2004)^{19}, \quad$ yang memperhatikan masalah bahasa dalam penelitiannya. Anna L. Tsing (1998), selain memahami bahasa Indonesia, peneliti juga mempelajari bahasa Dayak-Banjar, serta dialek istilah-istilah lokal dalam bahasa campuran Indonesia-Banjar yang biasanya digunakan oleh masyarakat setempat. Hal ini penting bagi peneliti, untuk memahami puisi-puisi, dongeng-dongeng, ataupun mantera-mantera yang diucapkan oleh informan.

Penelitian di cafe kampus, saya seolah seperti tidak perlu memperhatikan bahasa, karena tidak ada wakil etnis tertentu yang menggunakan bahasa daerah di sana. Jika berbagai etnis dengan berbagai bahasa daerah ada di sana, namun karena lingkungan kampus maka orang akan menggunakan bahasa Indonesia sebagai bahasa resmi.

\section{b. Mencari dan Memilih Informan}

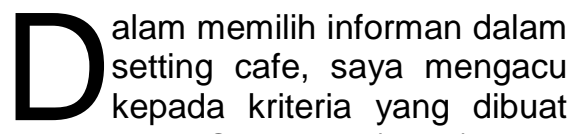
Spradley. Menurut Spradley (1997), ada lima persyaratan minimal untuk memilih informan yang baik, yaitu:

(1) Enkulturasi penuh. Informan yang baik mengetahui budaya mereka dengan begitu baik tanpa harus memikirkannya. Mereka melakukan berbagai hal secara otomatis dan sudah mempunyai pengalaman informal selama bertahun-tahun.

(2) Keterlibatan langsung. Informan yang terlibat dalam suasana budaya mereka, menggunakan pengetahuan budaya tersebut untuk membimbing tindakannya. Ketika orang yang tidak lagi menggunakan beberapa bagian dari pengetahuan kebudayaannya maka pengetahuan itu sulit untuk diungkapkan kembali olehnya. Informan yang meninggalkan suasana budaya akan melupakan detail suasana itu dan hanya dapat mengingat garis besar secara umum berbagai aktivitas yang berlangsung.

18 Clifford geertz (1998). After the fact: Dua Negeri, Empat dasawarsa, Satu antropolog. Yogyakarta: Lkis.

19 Yekti Maunati (2004). Identitas Dayak: Komodifikasi dan Politik Kebudayaan. Yogyakarta: LkiS. 
(3) Suasana budaya yang tidak dikenal. Ketika etnografer mempelajari budaya yang tidak dikenalnya, maka ketidakkenalannya ini menahannya untuk menerima berbagai hal itu apa adanya. Sikap ini membuat mereka menjadi sensitif terhadap berbagai hal yang telah menjadi demikian biasa bagi informan tetapi mereka mengabaikannya.

(4) Waktu yang cukup. Dalam penelitian lapangan dibutuhkan serangkaian wawancara etnografis, sehingga perlu memperkirakan apakah calon informan itu cukup memiliki waktu untuk memberikan partisipasinya.

(5) Non analitis. Informan menggunakan bahasa mereka untuk men-deskripsikan berbagai kejadian dan tindakan dengan cara tanpa analisis dan atau memberikan analisis dan interpretasi mengenai berbagai kejadian itu dari perspektif 'teori penduduk asli', bukan dari perspektif orang luar.

Informan dengan kriteria "enkulturasi penuh" tentu saja adalah orang-orang atau pengunjung yang datang ke cafe untuk makan dan bersantai. Dari mereka inilah diperoleh informasi tentang simbol dan makna makan di cafe serta simbol dan makna tentang makanan. Agar wawancara berjalan lancar, saya menunggu informan untuk bersantap dulu, setelah itu baru saya wawancarai.

\section{c. Membangun Rapport}

$\mathrm{R}$ apport dengan informan perlu dibangun sebelum kita melakukan wawancara. Rapport peneliti merupakan hal yang sangat penting dalam melakukan penelitian. Rapport terkait dengan tingkat penerimaan suatu komunitas atau masyarakat terhadap keberadaan seorang peneliti. Semakin baik rapport penelitian, maka semakin mudah akses dalam pengumpulan data.

Walaupun tidak ada standar baku tentang bagaimana rapport dibangun, dan kiat-kiatnya, beberapa ahli tampaknya memiliki pendapat berbeda. Misalnya, Argyris (1952) mendefinisikan rapport sebagai komunikasi dengan penuh perasaan dan simpati kepada informan sehingga mereka menganggap kita sebagai bagian dari mereka. Erving Goffman (1959) mendefinisikan rapport sebagai upaya untuk membuat orang-orang menjadi terbuka atas dirinya, setting sosialnya. Berani menjelaskan dirinya dan tidak hanya posisi di front stage saja. Menurut Taylor, biasanya rapport peneliti akan membaik setelah ia lama berada di lapangan. Meskipun demikian, rapport juga bersifat tentatif (sementara) dan mudah berubah tergantung dari bagaimana perilaku dan pembawaan seorang peneliti. Biasanya, strategi agar peneliti bisa diterima adalah dengan cara melakukan aktivitas dari subyek informan. Dengan cara ini, biasanya informan akan melihat peneliti sebagai bagian dari dirinya sehingga tidak ada jarak ketika sama-sama melakukan berbagai aktivitas. Contoh lainnya, David W McCurdy (1976) yang berusaha dengan berbagai cara untuk tetap mempertahankan rapport dengan masyarakat desa Ratakote, sebuah desa terpencil di India, yang sedang ditelitinya, dimana peneliti harus melayani pengobatan kesehatan penduduk setempat. Yeti Maunati (2004), dalam membangun rapport, mengikuti kegiatan mengumpulkan kayu bakar selama musim kemarau, bersama kelompok perempuan. Ikut bekerja bergotong-royong membangun perluasan sebuah bangunan lamin, berpartisipasi mempersiapkan sejumlah festival. Pada setiap kesempatan, ikut berpartisipasi melakukan berbagai tugas yang dibebankan kepada kaum perempuan.

Dalam konteks penelitian ini, saya tidak merasakan adanya usaha keras dalam membangun rapport. Misalnya saja, ketika informan saya datangi di salah satu meja makan di cafe, lalu saya memperkenalkan diri dan menyatakan tujuan saya, sepertinya semua informan menerima saya tanpa saya harus susah-susah membangun rapport. Saya mulai berfikir, apakah karena topik dan informasi yang akan saya tanyakan tidak krusial atau tidak berbau konflik, sehingga informan saya tidak ada yang keberatan diwawancarai dan diminta informasi. Semua itu patut disyukuri saja, karena saya relatif tidak mengalami hambatan ketika melakukan wawancara.

\section{d. Pengamatan dan Wawancara} aya menyadari bahwa proses
penelitian antropologi ini harus
fleksibel dan berkembang secara
kontekstual sesuai dengan realita di 
lapangan $^{20}$. Oleh sebab itu dibutuhkan perlakuan yang fleksibel, karena bisa saja teknik-teknik yang telah dirancang dalam proposal penelitian mungkin tidak tepat digunakan ketika peneliti berada di lapangan.

Sejak awal dalam penelitian ini sebetulnya saya memang tidak berani mengatakan akan melakukan observasi partisipasi. Terpikir oleh saya, jika saya datang ke cafe dan ikut memesan makanan, ikut makan bersama informan, apakah saya sudah melakukan observasi berpartisipasi? Terlebih lagi menurut pemahaman saya, dalam melakukan pengamatan terlibat, saya sebagai peneliti akan berada dalam tingkat keterlibatan tertentu dalam hubungan saya dengan pelaku yang diteliti. Keterbatasan waktu dan tenaga, hal tersebut tidak mungkin saya lakukan.

Wawancara yang saya gunakan dalam penelitian ini adalah wawancara mendalam (setidaknya hanya dengan beberapa orang informan saja), dan tidak menggunakan pertanyaan terstruktur. Saya menyiapkan beberapa pertanyaan besar, lalu pertanyaan selanjutnya saya kembangkan dari jawaban-jawaban informan. Teman saya, Yusran Darmawan, dengan setia membantu saya dalam dokumentasi penelitian, baik dalam pengamatan maupun proses wawancara.

\section{e. Membuat dan Menyiapkan Fieldnote}

$\mathrm{S}$ etelah pengumpulan data dilakukan, saya mulai membaca dengan seksama banyak halaman catatan lapangan, yang kadang-kadang berlainan, tidak berkaitan antara peristiwa-peristiwa dan kejadian-kejadian, untuk mengenali urutan-urutan yang dapat disusun bersama, untuk menceritakan dunia sosial yang dipelajari dan diamati. Tujuannya adalah untuk menghasilkan sebuah pertalian yang logis, dengan memfokuskan analisis pada beberapa aspek kehidupan sosial yang telah diamati dan direkam, sebuah analisis yang menyeluruh untuk disajikan kepada para pembaca secara umum ${ }^{21}$. Namun secara jujur saya katakan, selama ini memang saya

\footnotetext{
${ }^{20}$ Grant \& Fine, 1992; Spradley, (1979) via Creswell, (2002:10).

${ }^{21}$ Setidaknya, ini yang dikatakan oleh Emerson dan Sanjek
}

belum melakukan secara rinci apa yang dikatakan oleh Emerson tersebut. Oleh sebab itu, apa yang saya lakukan sekarang dengan panduan dari buku Emerson tersebut amatlah menyita waktu dan saya menyadari betul kalau pekerjaan yang sepertinya mudah itu ternyata sangat sulit jika benar-benar dilakukan.

Kendala yang paling berarti bagi saya adalah dangkalnya pengetahuan saya akan teori-teori yang relevan dengan topik yang saya pilih untuk diteliti, sehingga saya kesulitan untuk membuat koding dan memoing. Jelas ini pengalaman yang paling berharga untuk bekal menyusun sebuah etnografi kelak.

\section{Catatan akhir}

$\mathrm{L}$ atihan penelitian yang dilakukan ini, akhirnya membuat saya sadar dan memiliki pengetahuan bagaimana seharusnya penelitian antropologi itu dilakukan. Seringkali dari kacamata 'luar', penelitian antropologi yang notabene menggunakan paradigma kualitatif, dianggap mudah, tidak begitu ilmiah, dan sebagainya, ternyata jika dilakukan benarbenar sebagaimana prosedur yang seharusnya dilakukan, bukanlah pekerjaan mudah.

Penelitian saya di cafe, tidak dalam satu komunitas dengan ciri kebudayaan tertentu, nampaknya berkaitan dengan bagaimana antropologi sebagai sebuah disiplin ilmu mampu merespons pergeseranpergeseran yang terjadi. Misalnya yang dicontohkan Abdullah (2006:189), tentang kaum muda. Jika mendefinisikan kebudayaan berdasarkan wilayah-wilayah kebudayaan (culture areas), kita akan gagal menemukan batas-batas wilayah tersebut karena kaum muda dapat dibaca sebagai "people on the move" yang merupakan aktor dalam proses deteritorialisasi budaya 


\section{Daftar Pustaka}

Abdullah (2006). Konstruksi dan Reproduksi Kebudayaan. Yogyakarta: Pustaka Pelajar

Appadurai A (1994). Global Ethnoscapes: Notes and Queries for Transnational Anthropology dalam RG Fox (ed) Recapturing Anthropology: Working in the Present. Santa Fe, NM: School of American Research Press.

Asad, Talal (1973). Anthropology and the Colonial Encounter, Ithaca: Humanities

Clifford, J.R.Marcus (1986). Writing Culture: The Poetics and Politics of Etnography. Berkley: University of California Press

Creswell, John W., 2002. Desain Penelitian: Pendekatan Kualitatif \& Kuantitatif (Alih bahasa: Angkatan III \& IV KIK-UI). Jakarta: KIK Press.

Ferraro, Gary, (1995). Cultural Anthropology: An Applied Perspective (2 ${ }^{\text {nd }}$ edition). Minneapolis/ St.Paul: West Publishing Company

Fetterman, David M. (1989). Ethnography Step by Step. Applied Social Research Methods Series Volume 17. Sage Publications: The International Professional Publishers Newbury Park, London, New delhi.

Foster, G.M. dan R.V. Kemper (1974). "Introduction: Perspective on Anthropological Fieldwork in Cities", dalam G.M. Foster \& Robert V Kemper (ed), Anthropologist in Cities. Boston: Little, Brown and Company. Hal. 1-18.

Geerzt, Clifford (1998). After the fact: Dua negeri, Empat dasawarsa, Satu Antropolog (alih bahasa Landung Simatupang). Yogyakarta: LkiS. 1998 : 67.

Kurotani, Sawa. (2004). "Multi-sited Transnational Ethnography and the Shifting Construction of Fieldwork" dalam dalam Anthropologist in the Field: Cases in Participant Observation, Lynne Hume \& Jane Mulcock (eds). New York: Columbia University Press.

Marcus, George E. (1998). Ethnography: Through Thick \& Thin. New Jersey: Princeton University Press

Muir, Stewart (2004). "Not Quite at Home : Field envy and New Age Ethnographic Dis-ease", dalam Anthropologist in the Field: Cases in Participant Observation, Lynne Hume \& Jane Mulcock (eds). New York: Columbia University Press.

Spradley (1997). Metode Etnografi. Yogyakarta: Tiara Wacana Yogya.

Tsing, Anna Lowenhaupt (2005). Etnography of Global Connection. New Jersey: Princeton University Press

Yekti Maunati (2004). Identitas Dayak: Komodifikasi dan Politik Kebudayaan. Yogyakarta: LkiS. 